\title{
THE TOXICITY OF PARAQUAT AND DIQUAT
}

\author{
D. J. T. HowE and N. WRIGHT \\ Imperial Chemical Industries, England
}

Summary

The facts as we know them support the view that although paraquat and diquat can be regarded as being moderately toxic in some species, their use as herbicides can be accomplished with a minimum of hazard and without elaborate precautions. Their safety in field practice is further enprecautions. Their safety icidal activity, which means that hanced by their high herbicidal achieve the desired effect, and by their non-persistence in an active and toxic form. Nevertheless, precautions as with all chemicals are necessary theless, precautions as wan lead to accidents in man or livestock.

\section{INTRODUCTION}

THE experimental toxicology of paraquat and diquat has been carried out in the Industrial Hygiene Research Laboratories of Imperial Chemical Industries Limited and the Industrial Bio-Test Imperial Chemical Industries Limited and A. The results of this Laboratories of Northbrook, Ilinois, with the findings of practical work are set out hereunder together with the findings of practical animal feeding studies carried out

\section{TOXIC EFFECTS}

ORAL TOXICITY - ACUTE

In the case of both diquat and paraquat there is considerable species variation in acute toxicity of single doses. The L.D.50 ranges frecies variation in acute $30 \mathrm{mg} / \mathrm{kg}$ in cattle to 400 to $800 \mathrm{mg} / \mathrm{kg}$ in from approximately the case of diquat ion, and $50 \mathrm{mg} / \mathrm{kg}$ in cattle to $300 \mathrm{mg} / \mathrm{kg}$ in hens in the case of paraquat ion.

The signs of poisoning vary to some extent with species, dosage,

The sibstance and usually develop gradually over many hours. and sibstance and in death in convulsions, and Massive doses quite often result in death in convulsions, and nervous symptoms are a feature of the effects of both substances. Respiratory difficulties also occur with both substances, but whereas after doses near to the L.D.50 of paraquat death in animals is due to respiratory failure, rats receiving such doses of diquat develop progressive abdominal distention due to impaired motility and dilatation of the large intestines and gradually become weak
until they die. Cattle show repiratory and nervois symptoms.

until they die. Cattle show r.D.50 (MG/KG) IN A VARIETY OF

TABLE 1: APPROXIMATE L.D.50 (MG/KG) IN A DARIT
SPECIES DOSED WITH PARAQUAT AND DIQUAT

\begin{tabular}{|c|c|c|c|c|c|c|c|c|c|c|}
\hline & & & & & & & & & Paraquat & Diquat \\
\hline \multirow{2}{*}{$\begin{array}{l}\text { Rat } \\
\text { Mouse }\end{array}$} & $\ldots \ldots$ & $\ldots \ldots$ & $\ldots \ldots$ & $\ldots \ldots$. & $\ldots \ldots$. & $\ldots .$. & $\ldots \ldots$ & $\cdots \cdots$ & 200 & 400 \\
\hline & $\ldots \ldots$. & $\ldots \ldots$. & $\ldots . .$. & $\ldots \ldots$. & $\ldots \ldots$ & $\ldots \ldots$. & $\ldots \ldots$ & $\ldots \ldots$. & - & 170 \\
\hline Rabbit & ....... & ....... & $\ldots \ldots$. & $\ldots \ldots$. & ....... & $\ldots . .$. & $\ldots \ldots$. & ........ & - & 190 \\
\hline Dog & $\ldots \ldots$ & $\ldots \ldots$. & $\ldots . .$. & $\ldots \ldots$. & $\ldots \ldots$ & $\ldots \ldots$ & ....... & ....... & - & $>200$ \\
\hline Hen & ....... & $\ldots . .$. & $\ldots \ldots$ & $\ldots . .$. & $\ldots . .$. & $\ldots \ldots$ & ....... & ....... & $300-380$ & $400-800$ \\
\hline Cow & $\ldots .$. & $\ldots . .$. & $\ldots \ldots$ & ....... & $\ldots \ldots$ & $\ldots \ldots$ & $\ldots \ldots$. & $\ldots . .$. & $50-75$ & 30 \\
\hline Guine & jig & $\ldots . .$. & $\ldots . .$. & $\ldots \ldots$. & ....... & ....... & ....... & $\ldots \ldots$ & $40-80$ & - \\
\hline Cat & $\ldots .$. & $\ldots .$. & $\ldots \ldots$ & $\ldots \ldots$. & $\ldots \ldots$ & ....... & ....... & $\ldots \ldots$ & $40-50$ & - \\
\hline Sheep & $\ldots \ldots$. & $\ldots .$. & $\ldots \ldots$ & $\ldots \ldots$ & ....... & ....... & ....... & ....... & $50-75$ & - \\
\hline
\end{tabular}




\section{ORAL TOXICITY - Chronic}

Rats and dogs have been fed for more than two years with varying proportions of either substance in their diet. A level of $125 \mathrm{ppm}$ of paraquat fed to rats for their life span was without toxic effect. Dogs were completely unaffected by $50 \mathrm{ppm}$ of paraquat in their diet for two years.

It was observed that both rats and dogs fed diets containing diquat developed cataracts after a while. Nevertheless, levels of $7.5 \mathrm{ppm}$ can be fed to rats for their life span without producing cataracts and dogs have been unaffected after three years a $70 \mathrm{ppm}$. Apart from cataract, growth and survival of rats are not affected by $350 \mathrm{ppm}$ of diquat in the diet. Feeding of paraquat has never produced cataract.

\section{EYE EFFECTS}

A $10 \%$ solution of diquat has no effect in the rabbit's eye; a $40 \%$ solution is a moderate irritant. A $40 \%$ solution of paraquat is more irritant, producing moderate inflammation after a delay of some hours. Nevertheless, accidental splashes in the eye must be avoided when handling the concentrated chemical as the must eye may be rather more susceptible to conjunctival irritation than that of the rabbit.

\section{DERMAL TOXICITY}

The single application of concentrated solutions of paraquat and diquat produces little inflammatory response on the skin of rats and rabbits. The L.D.50 for a single application of paraquat to rabbit skin is about $0.5 \mathrm{~g} / \mathrm{kg}$. A dose of this order of diquat produces only mild signs of systemic toxicity in some animals. However, the repeated application of much more diluted solitions of either substance has shown skin damage and systemic toxicity in animal experiments. These tests may, however, present an exaggerated picture of the dermal toxicity, either because occlusive dressings have caused maceration of the skin and destruction of the barrier to water-soluble compounds, or because the techniques did not totally exclude the possibility of oral contamination.

\section{ABSORPTION AND EXCRETION}

Experiments in rats using ${ }^{14} \mathrm{C}$ labelled material have shown that just over $10 \%$ paraquat and less than $10 \%$ diquat of an is absorbed, and excreted unchanged in the urine within 48 hours. The remainder of the activity can be accounted for in the faeces.

\section{EFFECTS IN MAN}

It is to be expected that the effects registered in animals would also be observable in man receiving doses or exposures to diquat and paraquat. No man has yet taken oral doses of either material for in eng periods, and, because very small or nil residues are recorded in edible crops where bipyridyls are used, there is unlikely to be any hazard of chronic toxicity to man. Therefore, there is no danger of the long-term effects of these substances, which have been reported in test animals, occurring in man.

Although the writers have no reports of fatal doses of diquat being taken, there have been reports of large doses of paraquat being taken by accident or for suicidal intent. In one case, after taking a 
massive dose, death was within hours, and with convulsions. In another, death was after a period of days and due to respiratory failure. The magnitude of the lethal dose of paraquat to man is not exactly known, but accidents suggest that it is above $25 \mathrm{mg} / \mathrm{kg}$. Doses above $400 \mathrm{mg} / \mathrm{kg}$ have proved fatal.

Experiment in man has revealed that the concentrated solutions are irritant to the skin and eyes and, moreover, that contact with the base of the nail may result in a disturbance of nail growth. In mild cases white patches appear on the nail; in severe cases the nail may crack at the base and be shed. The subsequent nail growth is entirely normal.

Workers exposed to a dust of diquat or paraquat or a mist of either have suffered from nose bleeding.

In summary, therefore, it can be said that paraquat and diquat are of moderate toxicity and moderately irritant in concentrated are of modion, with a specific effect on contact with the nails.

However, this represents only one side of the picture. Their use is remarkably free of hazard because, coupled with this only moderate toxicity:

(1) These substances become inactivated in contact with the soil.

(2) Very small amounts achieve the desired purpose. Concentrates of diquat and paraquat as sold to the farmer are aqueous solutions containing $20 \% \mathrm{w} / \mathrm{v}$ of their respective ions. Recommended dosage rates vary between $2 \mathrm{oz}$ and $2 \mathrm{lb}$ per acre of the ion, these amounts being diluted in $2 \frac{1 / 2}{2}$ to 50 gal of water depending on the method of application.

(3) Residues on edible crops are very low or undetectable (less than $0.01 \mathrm{ppm}$ ).

(4) Their rate of disappearance when used to kill aquatic weeds is such that they may be used when subsequently the water is to be ingested.

\section{EXPOSURE TO HAZARDS}

An examination can now be made of the means whereby man and animals may be exposed to these substances, the hazards that are encountered, and how they can be avoided.

\section{SPRAY OPERATIONS}

The special properties of diquat and paraquat as broad-spectrum contact herbicides - particularly their inactivation on contact with soil, and their rapid desiccant effect on all "green" plants irrespective of weather or climate - have opened up the possibility of using them in virtually all crops. In spite of their comparatively recent introduction, they are already in use throughout the world for weed control at sowing or planting, in orchards, vineyards and tropical plantation crops, as desiccants in potatoes and sugar cane, for aquatic weed control, for pasture improvement, and as a means of destroying previous crops in preparation for direct drilling without recourse to the plough. Such a variety of uses has called for many different application techniques, ranging from the watering-can in home gardens to large-scale aerial spraying operations

To discover the hazards to spray operators from paraquat, special tests have been carried out at the I.C.I. unit at Fernhurst in Sussex, Men used a variety of spraying equipment; drag dribble bar, knapsack sprayer, tractor-mounted low volume sprayer, and a watering-can. They wore additionally only gloves and goggles when handling concentrate, otherwise they wore their ordinary working 


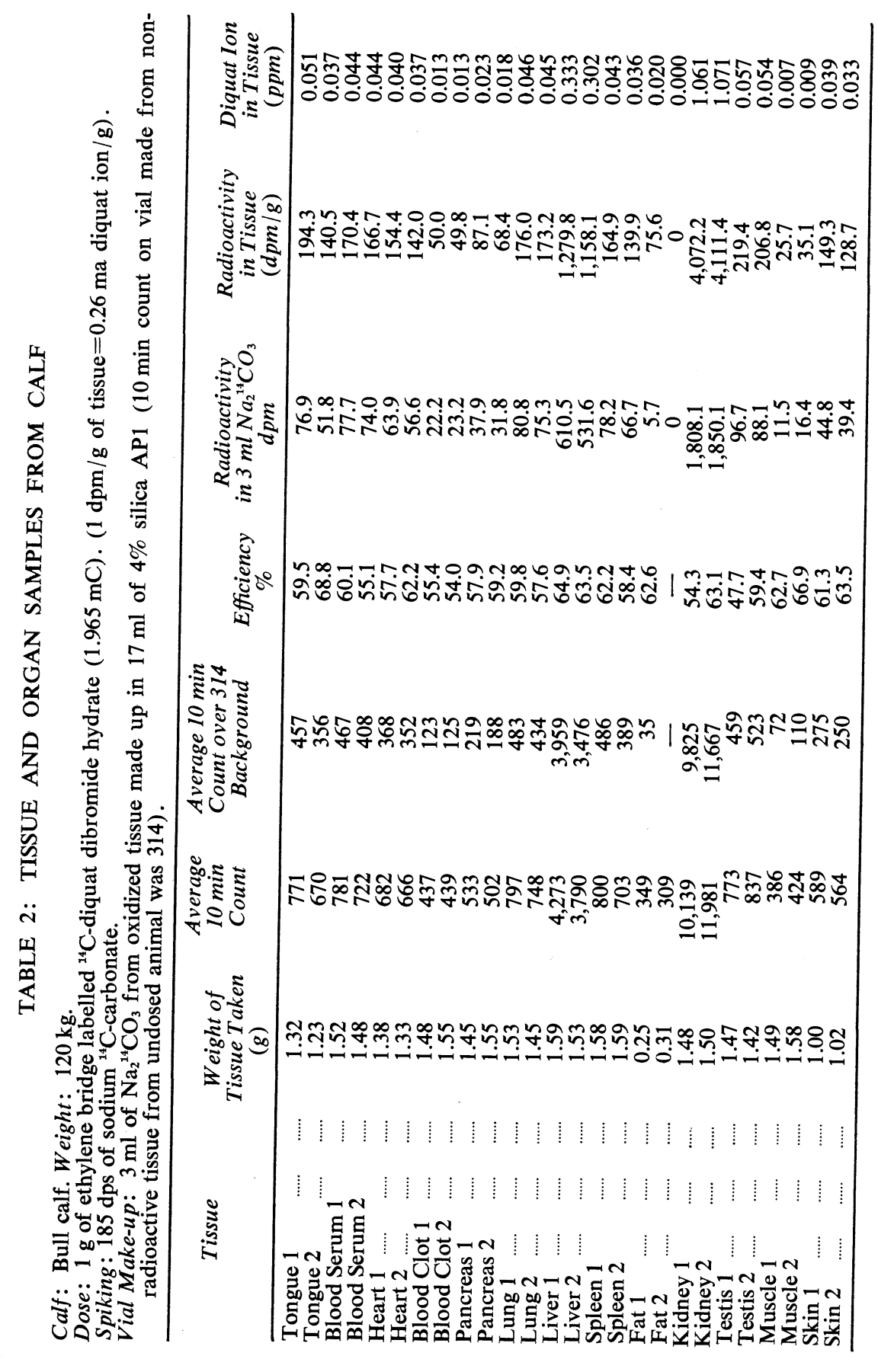

108 
dress. It was found that concentrate spilled on their skin but immedress. It was found that concentrate spilled on their skin but immediately washed off left no ill-effects. Their urine did not show the presence of paraqiat. Inadvertent inhalation of spray drift did. cause nose bleeding which cleared rapidly when exposure ceased. Careless handling of concentrate with bare hands did lead to the

shedding of a finger nail. The
tained during the experiment.

Severe nose bleeding has occurred in operators in Malaya using mistblowers to apply paraquat. It is considered that, because of the difficulty in enforcing the use and maintenance of an effective respirator, any process producing fine droplets of paraquat and diquat should not be contemplated.

No hazard should arise when other spraying methods are used provided that:

(1) Eye shields and gloves are worn when the concentrate is handled.

(2) Concentrate spilled on the skin is immediately removed.

(3) Inhalation of spray drift is avoided.

(4) Aerial spraying markers wear face shields, dust masks and cotton overalls.

\section{GRAZING ANIMALS}

Grazing animals are liable to ingest paraquat and diquat by feeding on a sprayed area, or as a result of spray drifting on to their pasture, or by their drinking water being contaminated with these substances. Table 1 shows that cattle and sheep are among the substances. most susceptible species to the toxic effects of paraquat the effects Experiments were carried out in Australia to discover the effects on those animals of the concentration likely to be encountered. The results showed clearly that eight-month-old sheep and calves can be given up to $20 \mathrm{ppm}$ paraquat or diquat in their drinking water for a period of one month without any obvious signs of ill-effect. There was no evidence that the animals drank less of the water because it was treated.

There is always the fear that traces of impurities ingested by There is always the fear that traces of impurities milk. Cows animals will leave residues in the meat and in the milk. Cows have been dosed with methyl labels approximately one-twelfth of the bridge labelled ${ }^{14} \mathrm{C}$ diquat at levels approximately one-twelfth of the acute oral L.D.50. The milk yielded contained less than $0.1 \mathrm{ppm}$ of paraquat or diquat ion. A cow dosed with two-thirds of the L.D.50 dose of nuclear labelled of this milk did not result in conless than $0.1 \mathrm{ppm}$. Processing of thuter, casein or whey fractions. centration of the diquat in the butter, casein or whey fractions.

Labelled diquat dosed to a calf at a level well in excess of residues found in fodder (e.g., straw from desiccated seed crops, desiccated silage) was found at slaughter 24 hours later to be less than $0.05 \mathrm{ppm}$ diquat ion in all but the liver and kidneys. Table 2 sets out these data.

In farm scale trials at Jealott's Hill, steers and milking cows In farm scale trials at 4 weeks on diquat-desiccated silage conwere fed continuously for 4 weeks milk was analysed during the taining 3 to $4 \mathrm{ppm}$ diquat ion. The milk was an the steers at last 2 weeks, the liver, kidney, lung and meat of the steers at
slaughter after 4 weeks. No detectable $(<0.01 \mathrm{ppm})$ diquat was found in any sample.

From the trials so far conducted it is apparent that (a) livestock From the any danger from drinking water which has been treated with bipyridyls for aquatic weed control, (b) the hazard to stock with bipyridyls for an pasture sprayed with a bipyridyl depends on 
the density of the pasture, the dosage employed and the length of time elapsing after application, (c) consumption of fodder containing residues of paraquat or diquat will not result in harmful residues in milk or meat, but maximiam allowable residue in the fodder has not yet been determined on a practical scale. The present recommendation is that stock should be kept off
freshly sprayed areas.

Further trials and field experience will enable more finite recommendations to be made.

Hay from seed crops desiccated with diquat is likely to contain residues which are only marginally safe for feeding to stock. Further experiments are in progress to test this point. In the case of silage, residues appear to be well within safe limits.

\section{Fish and Aquatic Fauna}

In Table 3 is listed the evidence available on the toxicity of diquat and paraquat to fish.

It can be seen that, although the toxicity of each substance to fish varies considerably with species, there is at least a tenfold factor in the safety margin between the normal dose used for aquatic weed control $(0.5$ to $1.0 \mathrm{ppm})$ and that which is toxic in 96-hour tests to the most sensitive species.

The median survival period of rainbow trout to $1 \mathrm{ppm}$ diquat is 10 to 15 days. Only $30 \%$ mortality is recorded in trout in this concentration of paraquat for 16 days

Diquat and paraquat can be detected in fish kept in $1 \mathrm{ppm}$ solutions of the herbicides. The residues are located in the gut, skin, The

The results of preliminary studies on the macrofauna in water treated with these herbicides show a decrease in abundance of largely herbivorous invertebrates and an increase in detritus feeders. The period over which measurements were taken corresponded to the destruction of vegetation and accumulation of decaying matter yielding an increase in all particle sizes of detritus. The most likely cause of the decreased abundance of herbivores would be by direct starvation through lack of food. According to W. M. Tatum et al. (Proc. SE Assn. Game and Fish Commission, 1962), $0.5 \mathrm{ppm}$ diquat does not change the population of bottom fauna and plankton.

The most significant fact bearing upon the safety of these herbicides for aquatic weed control is the rapidity of their disappearance due to uptake by weeds, adsorption by soil particles, and photochemical degradation. From between 4 and 7 days after application of $1 \mathrm{ppm}$, less than $0.1 \mathrm{ppm}$ can be detected.

A few cases have been reported of fish succumbing in enclosed ponds and lakes treated with bipyridyls. These have been investigated very carefully and it seems that the most likely caise of death has been the de-oxygenation of the water resulting from the absence of photosynthetic activity and consumption of oxygen by decomposing vegetation. Such analyses of bipyridyl residues in the dead fish as were possible indicated amounts well below toxic levels. As a practical precaution, avoiding the spraying of a whole water area at one time is a relatively simple expedient for meeting this type of hazard.

The rapid disappearance of these herbicides renders them particularly safe for the treatment of aquatic weeds when subsequently the water will be used as potable water for dwelling houses. 
TABLE 3: TOXICITY OF DIQUAT AND PARAQUAT TO FISH COLLECTED DATA

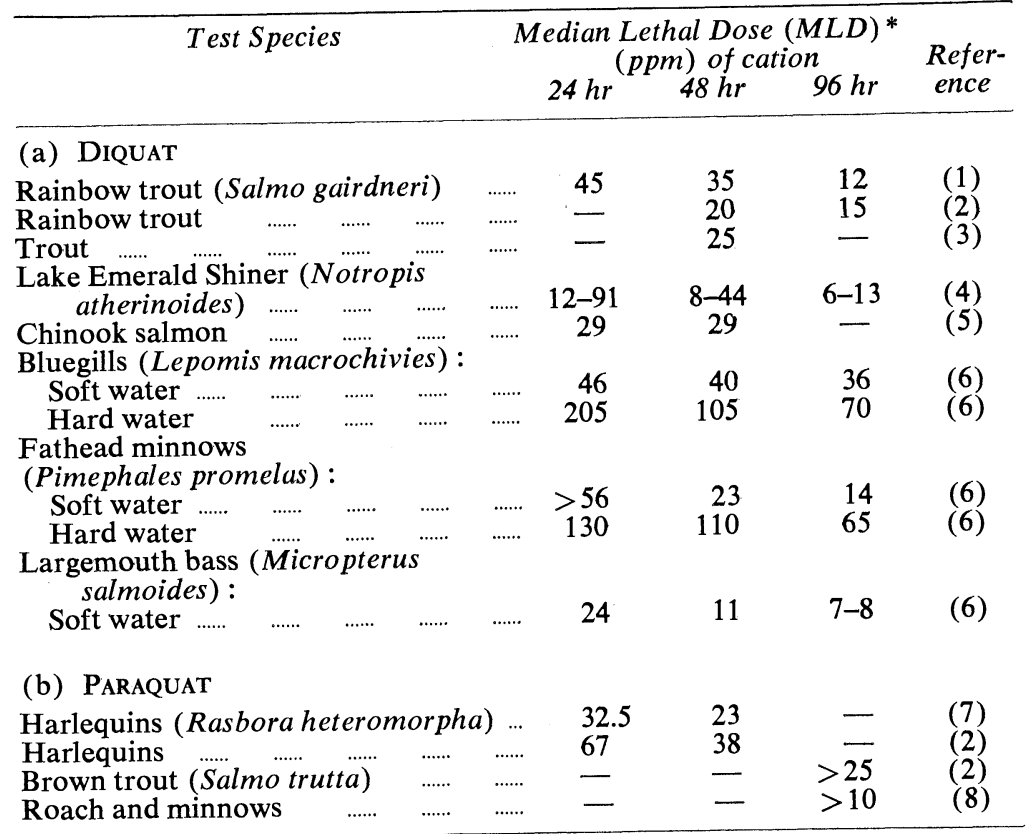

* In the U.S.A., Tolerance Lethal Medium (TLM) is used.

REFERENCES:

(1) Alabaster, J. S., 1959: Min. Agric. U.K.

(2) Carter, L., 1963: I.C.I. Marine Res. Station.

(3) Merck, E., 1964.

(4) Swabey; Schenk, 1963: Proc. 3rd Ann. Mtg. Aquatic Weed Control Soc., Chicago.

(5) Bond; Lewis; Fryer, 1960: Robert A. Taft Sanit. Eng. Centre Tech. Rep.: 60-3.

(6) Suber; Pickering, 1962: Progressive Fish Culturist, 24.

(7) Alabaster, J. S., 1961: Min. Agric. U.K.

(8) Wurtz-Arlet, J., 1963.

\section{WILD LIFE}

At this stage it is worth mentioning briefly the effects of these herbicides on wild life. Since they are readily excreted and are not retained to any extent in body tissue, only massive acute doses can inflict injury or death to wild life.

In America experiments have shown that ducks and pheasants were unaffected by $11,000 \mathrm{ppm}$ and $17,000 \mathrm{ppm}$, respectively, of paraqiat fed to them for 10 days. In each case this was the maximum they would take.

Animals which may feed on freshly sprayed pasture or stubble weeds, such as hares, may in certain circumstances be exposed to risk; they could also be affected by licking their coats after saturation with the spray. From considerable practical experience in 
the use of paraquat in arable land, such hazards appear to be negligible although a few unsubstantiated instances of hare mortality have prompted closer investigation, now in progress.

On present evidence, there is no reason for recommending any special precautions for wild life protection.

\section{EdibLE CROPS (human consumption)}

The weed control uses of the bipyridyls fall necessarily into three categories: (1) Tree or bissh crops where the basal bark protects the crop from chemical damage, (2) Annual or biennial crops where special machinery is used to prevent spray reaching the crop, (3) Weed control before planting or emergence of the crop above ground. From many analyses of crops in all these categories, taken from many countries, nil residues have been found at harvest and registration of such uses is proceeding normally.

Outlets for pre-harvest desiccation present a different problem in that application of the bipyridyl is direct to the crop. For haulm destruction in potatoes the residues found in tubers expressed as means of a wide range of analyses are shown in Table 4.

TABLE 4: MEAN RESIDUES IN POTATOES AFTER HAULM DESTRUCTION

\begin{tabular}{|c|c|c|c|c|c|c|}
\hline & & & & & Rate (lb ion/acre) & Residue (ppm) \\
\hline Diquat ...... & $\ldots \ldots$ & $\ldots \ldots$. & $\ldots \ldots$ & $\ldots \ldots$. & $\begin{array}{l}0.25 \\
0.5 \\
0.7( \pm 0.05) \\
1.0( \pm 0.125) \\
3.0\end{array}$ & $\begin{array}{l}0.01 \\
0.01 \pm 0.011 \\
0.02 \pm 0.014 \\
\text { N.D. } \\
0.05\end{array}$ \\
\hline Paraquat & $\ldots \ldots$ & $\ldots \ldots$ & $\ldots \ldots$ & $\ldots \ldots$ & $\begin{array}{l}0.25 \\
0.5 \\
0.75 \\
1.0\end{array}$ & $\begin{array}{l}0.02 \\
0.04 \\
0.05 \\
0.07\end{array}$ \\
\hline
\end{tabular}

The limit of detection in these experiments was $0.01 \mathrm{ppm}$. Residues of this order would not present any hazard to consumers.

Turning to seed crops, residiues vary quite widely depending on whether the edible part of the crop is more or less protected at the time of spraying. Thus no detectable residues of diquat have been found in dehusked (polished) rice, the flour from desiccated wheat, the oil expressed from sunflower and sesame seeds. Further work is needed on such potential uses for diquat - inparticular, residue analyses from crops grown under different climatic conditions. The cereals, being important staple food crops, need to be investigated under local conditions to determine the variability of residue levels and the effect on these levels of the various processes sich as milling, malting, and baking to which cereals are subjected before consumption.

Diquat is the more commonly chosen bipyridyl for desiccation; it is less easily adsorbed to plant surfaces and more easily decomposed by light than paraquat and thus residues tend to be lower and possible effects on germination of seeds reduced. In the present state of our knowledge it can only be stated that, subject to confirmation in local experiments, the whole grain of all small-seeded cereals will contain higher residues of diquat than are acceptable for human consumption as a staple food but that, where the outer 
TABLE 5: SUMMARY OF DIQUAT AND PARAQUAT RESIDUE IN CROPS

$($ N.D. $=$ not detectable at limits of $0.005-0.1 \mathrm{ppm})$

\begin{tabular}{|c|c|c|c|}
\hline \multirow{2}{*}{$\begin{array}{l}\begin{array}{l}\text { Object of the } \\
\text { Application }\end{array} \\
\begin{array}{l}\text { Weed control in } \\
\text { orchards and } \\
\text { vineyards }\end{array}\end{array}$} & Crop & \multicolumn{2}{|c|}{ Residues found ppm } \\
\hline & $\begin{array}{l}\text { Apples, grapes, pears, } \\
\text { peaches, plums, cherries }\end{array}$ & N.D. & N.D. \\
\hline $\begin{array}{l}\text { Weed control in } \\
\text { soft fruits }\end{array}$ & $\begin{array}{l}\text { Blackcurrants, red- } \\
\text { currants, raspberries, } \\
\text { strawberries, logan- } \\
\text { berries, blue berries }\end{array}$ & N.D. & N.D. \\
\hline $\begin{array}{l}\text { Pre-emergence } \\
\text { weed control at } \\
\text { commercially } \\
\text { recommended } \\
\text { rates }\end{array}$ & $\begin{array}{l}\text { Barley, corn, oats, } \\
\text { wheat, potatoes, beans, } \\
\text { beetroot, carrots, peas } \\
\text { turnips }\end{array}$ & N.D. & N.D. \\
\hline $\begin{array}{l}\text { Post-emergence } \\
\text { weed control - } \\
2 \text { to } 3 \text { months } \\
\text { before } \\
\text { harvesting }\end{array}$ & $\begin{array}{l}\text { Barley, corn, oats, } \\
\text { wheat, potatoes, } \\
\text { beans, peas, } \\
\text { tomatoes, turnips, } \\
\text { flax, asparagus }\end{array}$ & N.D. & N.D. \\
\hline \multirow{11}{*}{$\begin{array}{l}\text { Pre-harvest } \\
\text { desiccation }\end{array}$} & Potatoes & $<0.02$ & generally $<0.1$ \\
\hline & Onions & $\leqslant 0.05$ & $<0.5$ \\
\hline & Carrots & - & $<0.1$ \\
\hline & Clover & $\begin{array}{l}\text { Regrowth } 1.0 \\
\text { (dry) 6.0 (1-2 } \\
\text { weeks) }\end{array}$ & - \\
\hline & Grass & 13.0 (dry) & $>100$ (dry) \\
\hline & & $\begin{array}{l}\text { within 1 week } \\
\text { Regrowth N.D. }\end{array}$ & $\begin{array}{l}\text { Regrowth } \\
<0.5 \text { (dry) }\end{array}$ \\
\hline & Grass/clover for silage & 0.3 & - \\
\hline & $\begin{array}{l}\text { Rice (without husk or } \\
\text { polished) }\end{array}$ & N.D. & - \\
\hline & $\begin{array}{l}\text { Sunflower seed, horse } \\
\text { beans, maize, mustard } \\
\text { seed }\end{array}$ & N.D.-1 & N.D.-1 \\
\hline & Wheat flour & N.D. & \\
\hline & Sugar cane juice & - & N.D. \\
\hline
\end{tabular}


husk is removed before eating - e.g., wheat and rice - nil residues are likely to be foind. For crops such as these, diquat residues in excess of $0.07 \mathrm{ppm}$ are unlikely to be acceptable by health authorities on the basis of present toxicological information.

Paraquat may be applied as a pre-harvest desiccant to sugar cane to facilitate harvesting and experiments have confirmed that this practice leads to undetectable residues (less than $0.005 \mathrm{ppm}$ paraquat ion) in the crushed juice. Rate of application was $0.5 \mathrm{lb}$ ion/ acre and harvesting 10 days after spraying.

The general residue levels of diquat and paraquat are summarized in Table 5. These averages have been calculated from the analyses of many hundreds of crop samples taken from field trials.

\section{SAFETy OF WATER to MAN AND CROPS}

Use of bipyridyls for water-weed control is being widespread not only because these herbicides are very efficient in this field but because, at the low rates required for herbicidal effect ( $1 \mathrm{ppm}$ on submerged weeds), they do not present a hazard to fish or stock. This has already been referred to. In the case of man, authorities rightly set stricter tolerances, and therefore the present recommendation to avoid drinking for 7 to 10 days after treatment is considered to be wise until further field experience is gained.

Furrow irrigation of crops using water treated with bipyridyls can be confidently recommended because their rapid adsorption to clay minerals and soil organic matter renders them innocuous. Overhead irrigation direct from a treated source misst not, however, be allowed within 7 days of treatment. 